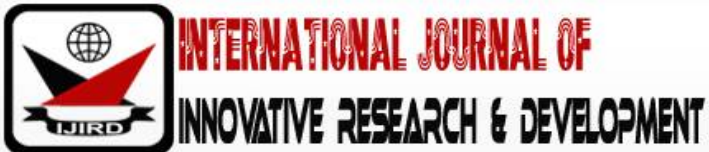

ISSN 2278-0211 (Online)

\section{Neo-Marxism and Post-Marxism: Dimensions, Discourses in Theoretical Modification and Development}

\author{
Dr. Essien, Blessing Stephen \\ Lecturer, Department of Sociology and Anthropology, University of Uyo, Nigeria \\ Dr. Okon, Donatus Efiok \\ Associate Professor, Department of Sociology and Anthropology, University of Uyo, Nigeria
}

\begin{abstract}
:
The saying that 'no theory is sacrosanct' is justified in Marxism specially when juxtaposes the obsessions of the NeoMarxists and Post-Marxists against Marxism as a socio-political and economic theory. This paper therefore undertook a discussion on Marxism, Neo-Marxism and Post-Marxism with the primary aim of noting the consensus and dissensus arising there from these two broad perspectives within the Marxian paradigm. The discourses centred on the dimensions and thematic areas that underlie the central nucleus of Marxian theory. The paper noted that though Neo-Marxist and Post-Marxist are Marxists in outlook and orientation, their perspectives differ significantly from the traditional Marxism. Both Neo-Marxist and Post-Marxist are receptive of ideas from functionalism, system theory and rational choice theory and therefore advocated for conflict- structuralism within Marxism.
\end{abstract}

Keywords: Marxism, Neo-Marxism, Post-Marxism, theory, modification

\section{Introduction}

Neo-Marxism and Post-Marxism are strands of ideas that emerged out of the philosophy and ideology of Karl Marx. Both could be regarded as meta-theories because they hoped to expand and present Marxian theory in quite a different paradigmatic view point but with anchorage on the traditional Marxism. Moreover, since both theoretical orientations are essentially the offshoot of Marx's ideas, they are an embellishment of Marx's idea in a more systematic manner in order to explain and provide an all embracing and tenable answers to contemporary social and economic relations, situations and conditions.

Karl Marx, born in 1818 and died in 1883, a German Economist-cum-Sociologist is the father of Marxism. Marxism as a sociological orientation and ideology examined the structure of society and the social and economic forces that engendered its change. Therefore, discussion on Neo-Marxism and Post-Marxism would not be meaningful without a comprehensive understanding of the underpinning assumptions, postulates and tenets that underline Marxism. Hence, this paper discusses Marxism, Neo-Marxism and Post-Marxism with the primary aim of noting the consensus and disagreements arising there from the two broad perspectives within the Marxian paradigm.

\section{Marxist Theory}

The basis of Marx's sociology is materialism and Marxism as a sociological theory traditionally involves two main postulates. The first relates to the structure of society and its development (Economic determinism). As Timasheff states in his Sociological Theory, its Nature and Growth (1957): "the organization of production (called by Marx the economic infrastructure of society) not only limits but also, in the final analysis, shapes the whole super-structure: political organization, law, religion, philosophy, art, literature, science and morality itself" (see Appendix A). The second postulate relates to change in society through three phases: Thesis (affirmation), Antithesis (negation) and Synthesis (reconciliation). This continuous dialectical process typifies change as a dynamic phenomenon of the abstract, physical and social world. Hence, the Marxists see change as resulting from contradiction inherent in all systems. For instance, Hegel sees change as a product of contradictory ideas while Karl Marx attributes it to contradiction in material world.

Marx idea of change is inevitably embedded in his understanding of the nature of society. Marx's idea of society consists of men with insatiable tastes and needs who organize themselves in order to satisfy their needs. In other words, necessity of men gives rise to cooperation and social group formation. He saw people as basically productivity; that is, in order to survive people must work in and with nature. Their productivity is a perfectly natural way by which they express basic creative impulses. These impulses are expresses in concert with other people; in other words, people are inherently social (Ritzer, 1996:26).

Marx enthused that the relations that are thus established between people in the course of production becomes the relationship between class of those who own the means of production and appropriate for themselves the results, outcome or efforts of the labour who are deprived of the means of production and who have only their labour to offer and thus compelled, by the survival instinct, to work for the former (Haralambos and Heald, 1980). To Marx, change was brought about by people struggling, albeit, physically, for material things. He traced change in history to class struggle and this he espoused in his "The Communist Manifesto" (1848), when he stated that "the history of all hitherto existing society, is that of class struggle ...." This has fast become a universal theory. 
Marx perception of Western capitalist societies is that of being conflict ridden, breeding class consciousness and unavoidable class conflict which, with time will destroy the existing social system and lead to a new social order. He stated that it was in capitalism that barriers are erected between the individual, production process and the products of that process. This is to him the very meaning of alienation. Since capitalism is exploitative, Marx was optimistic that its eventual collapse will not be too long. For Marx, the seed of its (capitalism) destruction is in the very belle of the monster (Andre, 1975). He states that, "the bourgeois relations of production are the last antagonistic formofsocial process of production-antagonistic not in the sense of individual antagonism, but of one arising from the social conditions of life of the individuals; at the same time the productive forces developing in the womb of bourgeois society create the material conditions for the solution of the antagonism" (Fletcher, 1972:385).

Marx therefore envisioned a new form of society devoid of class distinction where everybody will have equal chance of production and enjoying what he produces communally- "for each according to his needs, to each according to his abilities" (Andre, 1975). Marx submits that looking through the four epochs or stages of society's evolution and development, namely: Primitive Communal Stage, Stage of Slavery, Feudal Stage and the Capitalist Stage. The cycle does not end with capitalism but in socialism which does not contain elements of dialectics. Socialism will eventually make way for the final and last world order which is communism; a human society according to Marx (see Appendix A). In Marxian view therefore, contradictions will die at the capitalist stage while a new world order-communism would be the people's Eldorado devoid of all encumbrances inherent in the capitalist system. By attributing the cause of change, progress and development of society to material elements of society instead of abstract ideas, Marx theory is described as historical materialism. Every disciples of Karl Marx, takes a queue from here. Scholars like Karl Kausky, Friedrich Engels and Eduard Bernstern orchestrated these even after the death of Karl Marx.

Summarily, Marxism as a theory is engrossed with the following:

- An attention to material conditions of people's lives and social relations among people.

- A belief that people's consciousness of the conditions of their lives reflects these material conditions and relations.

- An understanding of class in terms of differing relations of production and as a particular position within such relations.

- A view that class struggle between classes in each historical period is a driving force towards historical change.

- Sympathy for the working class or proletariat.

- And a belief that the ultimate interests of workers best match those of humanity in general (Kolakowski, 1978).

The foregoing therefore laid the foundation for the comprehension of the fundamental ideology behind Marxism as a sociological orientation. Marxism has suffered some damaging criticism and remedying these criticisms it was that gave rise to Neo-Marxian social thought. Attention will now be shifted to Neo-Marxist theory as they differ slightly from Marxism in their theoretical approach.

\section{Neo-Marxian Theory}

Neo-Marxism refers to a variety of twentieth century theoretical approaches that expand, amend and extend Marxism and Marxian theory by actually incorporating elements of other intellectual traditions into mainstream Marxism. It includes Hegelian Marxism, Critical theory, Neo-Marxist Economic Sociology and Historical Oriented Marxism (Ritzer, 1996). It sometimes appears in the heading "New Left Thinking" and refer to strands of theoretical orientation critically in search of a more subjective and applicable model of explaining real life situations than relying heavily on the traditional Marxian orientation base wholly on material relationship. Neo-Marxian hopes to re-brand, repackage and garnish Marxian ideas to meet contemporary intellectual demands. It is exemplified in the works of GeorgLukacs, Antonio Gramsci, JurgenHabermas and Immanuel Wallerstein. How NeoMarxists ideas differ from Marxism would be juxtaposed in the discourse of Marxism versus Neo-Marxism.

\section{Marxism versus Neo-Marxism}

Basically, Neo-Marxists were not dissatisfied with the entire gamut of Marx's ideas rather, they were critical of certain themes that formed the central focus of Marx philosophy. The dimensions of Marx's ideas in conjunction with the neo-Marxists would be adumbrated under the following thematic areas:

\subsection{Economic Determinism}

Karl Marx throughout his work considered the economic system of paramount importance and thus argued that it exerts primary influence and largely shapes other aspects of society (Ritzer, 1996; Appendix A). Contrary to Marx's view, the Neo-Marxian acknowledged the importance of the economic sub-system of the society but however disagreed with him on economic system directing the course of other sub-systems. The Neo-Marxists argued that Marx could not have taken such a deterministic position since emerging ideas revealed that other institutions of society affect economy, just as they are affected by it (Ritzer, 1996). It is the belief of the Neo-Marxist that Marx has reduced other institutions to epiphenomena to be influenced by one institution. The NeoMarxists therefore emphasized system interdependence and by so doing integrates elements of structural-functionalism and system/organic analysis into Marxism.

\subsection{Fetishism of Commodities}

The Neo-Marxists also expanded Marx's view of fetishism of commodity. Karl Marx believed that capitalism has created a social evil in which man has no control over the objects of his creation-Alienation. For him "the object that labour produces, its product confronts it as an alien being, as a power independent of the producer" (Haralambos and Heald, 1980). This occurs when man regards the products of his labour as commodities, as articles for sale in the market place. The objects of his creation are then seen to control his existence. Marx in doing this makes the product assume the super-organic quality and therefore reified. But for GeorgLukacs, a Neo-Marxist, man is not alienated by the product of his creation, commodity is at base a relation among people, they are produced by people and people give them their value, and so values should not be seen as produced by a market that is independent of the actor (Ritzer, 1996). Lukacs therefore reasoned that it would be illogical and ultimately irrational to assume that the producer is completely detached from the product he produces. Hence, rationality is at the centre of economic relation. Given this idea, Lukacs attempts to incorporate Weberian rationality into mainstream Marxism. 


\subsection{Class Consciousness and Revolution}

Extensive inputs have been added to Marx's class consciousness leading to social revolution and change. For instance, Marx was of the opinion that "the mode of production in material life determines the social, political and intellectual life processes in general" thus, eulogizing the overwhelming influence of the economic structure over the superstructure. In another instance he states that "it is not the consciousness of men that determines their being, but, on the contrary, their being determine their consciousness. In other words, the working class becomes conscious of themselves (disadvantaged position) simply through production relation and not merely by social existence. In Marx's view, a radical change in structure of society occurs when a class is transformed from a "class in itself" to a "class for itself". Moreover, when a class becomes a class for itself, the contradiction between the consciousness of its members and the reality of their situations is ended (Haralambos and Heald, 1980). ButAnthonio Gramsci, a Neo-Marxist though acknowledged historical regularities in society, however, rejected the idea of automatic or inevitable historical developments. Gramsci (1917/1977) believed that the masses have to develop a revolutionary ideology for the structural change to take place, which they do not do so, because they mostly resign to fate. Gramsi reasoned that for a revolutionary action to take place, the masses need the support and help of social elites who will raise the struggle from the level of economic necessity to the level of conscious aim and effective class consciousness (Lukacs, 1922/1968:76). Gramsci, also believed that for a revolution to succeed, the control of economic structure of society is not enough, it is also necessary to gain cultural leadership over the rest of society. Whereas economic Marxists emphasized the economy and coercive aspects of domination as leading to revolution, Gramsci, a Neo-Marxist emphasized cultural leadership or hegemony as the foundation of revolutionary actions (Charles, 2005).

\subsection{Domination and Control}

Most of the early Marxian theorists saw domination as specifically rooted at the level of economy. ButTrent Schroyer (1970) a Critical theorist suggested that the locus of domination in the modern world have shifted significantly from the economic to the cultural realm (the culture industry). He observed that Technology has tended to wield overwhelming influence over man; particularly, the mass media. Schroyer(1970) was concerned with the falseness the mass media has and its influence on the people. For him, the media mass is the now superstructure because it produces, repackages and disseminates set of ideas that seem to have pacifying, repressive and stupefying effects on the people (Cook, 1996). Equally, Herbert Marcuse (1969), criticized modern technology at least as it is employed in capitalism. He saw technology in modern capitalist society as leading to totalitarianism. In fact, he views it as leading to new method of external control over individuals (Ritzer, 1996:142). It is a means of dominating people and it serves to suppress individuality. He reasoned that the actors' inner freedom has been invaded by modern technology. Individuals cannot think critically and negatively about society, this gives rise to one "dimensional society" according to Marcuse. Hence, technology no matter how "pure" sustains and streamlines the continuum of domination. This vital link according to Marcuse can only be cut through a revolution. He however, agreed with Marx that technology is not inherently a problem and that it can be used to develop a better society (Marcuse, 1969: 56). Marcuse in line with Marx saw revolution as an instrument of effecting change and a means to end domination and control.

Unlike Marx and Marcuse, Harry Braverman was a critic not of science and technology per se but simply of the way that they are used in capitalism. That is "as a weapon of domination in the creation, perpetuating and deepening of gulf between classes in society" (Braverman, 1974:6). For him, science and technology have been used systematically to rob work of its craft and heritage without providing anything to take its place. Braverman then believed that in different (that is socialist) hand, science and technology could be used differently to produce an age that has come into being, in which, for the workers, the craft satisfaction that arises from conscious and purposeful mastery of the labour process will be combined with the marvel of science and the ingenuity of engineering, an age in which everyone will be able to benefit, in some degree, from this combination. More so, given Marx's concept of "superstructure", critical theorists shifted their attention to the "Cultural Industry" to discover the impact on the individual. They were concerned basically about firstly, how this industry produces falseness by packaging of ideas, mass produced and disseminated them to the masses by the media. Secondly, it's pacifying, repressive, and stupefying effect on the people (Cook, 1996, Friedman, 1987, Tarr, 1977, Zipes, 1994).

In other words, mass culture is regarded as instrument of capitalist ideology and forms of capitalist domination. In his study of television as part of the culture industry, Kellner (1990) sees the television as a threat to democracy, individuality and freedom and offer suggestions to deal with this threat. Even Schroyer (1990) have also found oppression in the knowledge industry (university and research institutes). Their autonomy has allowed them to extend themselves beyond their original mandate.

Also expanding critical theorist ideas on domination and control was Habermas whose major concern was to distinguish between work and interaction in which Marx ignored. His key point of departure from Marx is that communicative action (interaction) and not purposive rational action (work) is the most distinctive and most pervasive human phenomenon. It is not work the foundation of all socio-cultural life as well as all human sciences. Whereas, Marx was led to focus on work, Habermas is led to focus on communication. Marx base line was a communist society with undistorted work (species-being), for Habermas, the base line was a society of undistorted communication (communicative action). In terms of immediate goals, Marx seeks the elimination of (capitalist) barriers to undistorted work, but Habermas is interested in the elimination of barriers to free communication (Habermas, 1994).

\subsection{Labour and Capital}

Another strand of neo-Marxism is neo-Marxian Economic sociology whose major concern is a refocus on economic institution in modern capitalist society. Essentially, their focus is on the broad issue of capital and labour, it was Marx's view that capitalism is a competitive market in which one industry has unfettered control over the market. But Paul Baran and Paul Sweezy (1966) argued with Marx by claiming that competitive capitalism has been replaced by monopoly capitalism. In their argument, Marx competitive capitalism hinges on capitalists lowering prices for higher sales, but, in the monopolists capitalism, firms no longer have to compete in this way because one or a few firms control a market, competition shifts to the sales domain in which advertising, packaging and other methods of appealing to potential customers are the main areas of competitiveness.

The disadvantage associated with price competition is that it leads to chaos as a result of lowering of prices (bankruptcy and less profit), but sales competition adds to the profit since prices are high and even gives work to advertising industry. Also noted 
was the fact that in monopoly capitalism, large stockholders and managers control are the key players in the industry whereas, in competitive monopoly are entrepreneurs whose aim are at maximizing profit at a short run. Hence, the competitive capitalism places power and control in the hands of the entrepreneurs while monopoly capitalism gives financial independence and possession of a good dose of political power on the managers as seen by Baran and Sweezy in Ritzer, (1996: 153). Accordingly, Ritzer (1996) surmised that the economy of scale is today more important than price competition and managers today are the engines of business rather than entrepreneurs hitherto emphasized by the scientifically economic oriented Marxists.

\subsection{World System (Exploitation and Domination)}

Historically Oriented Marxism is another brand of Neo-Marxian theory. It is popularized by Immanuel Wallerstein and concerned majorly in carrying out extensive historical research on pre-capitalist economic formations which is central to Marxism. Unlike Marx who saw conflict to be between two unequal classes, Wallerstein saw domination and exploitation to be found within the world system where the core geographical areas lord it over the periphery and the semi periphery (Wallerstein, 1974.15). His world system is a self-contained social system with a set of boundaries and a definable life span that does not last forever (Wallerstein in Ritzer 1996:163). His idea of system did not seem to suggest an embodiment of consensus in the light of the functionalists' idea, but rather a variety of forces that are in inherent tension. He saw that these forces have the potential of tearing the system apart (Ritzer, 1996:163).

Wallerstein argued that the key to capitalism lies in the core dominated by a free labour market for skilled workers and a coercive labour market for less skilled workers in the peripheral areas. Such a combination is the essence of capitalism. He felt that if free labour market should develop throughout the world, we would have socialism. Wallerstein saw capitalism as an economic alternative to political domination. He listed three factors leading to the rise of capitalist world-economy out of the ruins of foundation: geographical expansion through exploration and colonization, development of different markets of labour control for zones of the world-economy and development of strong states that were to become the core states of the emerging capitalists" world-economy (Wallerstein, 1974:18). By shifting attention from small entities as social classes and workers to large scale social structure as the world-system as the potent source of exploitation and domination, Wallerstein differs considerably from Marx on the source of conflict and form of domination in the social system.

\section{Marxism versus Post Marxist Theory}

Post-Marxist theories are set of theories that reject many of the basic premises of neo-Marxist theories. Post-Marxist theories as discussed here involve a synthesis of Marxian theories with other theories, ideas and methods. There are diverse movements within Post-Marxist theories. They include: Analytical Marxism (Rational choice and Game theoretical Marxism) and post-modern Marxian theory (Ritzer, 1996).

Analytical Marxism is championed by John Roemer and hopes to synthesize non-Marxist methods and Marxist theory (Weldes, 1989). For instance, Cohen (1978) is of the view that rather than describe Marx as an exotic dialectician, he was a functionalist. He offers the following examples of functional explanations in Marx's work:

- Relations of production correspond to productive forces

- The legal and political superstructure rises on a real foundation

- The social, political and intellectual process is conditioned by the mode of production of material life.

- Consciousness is determined by social being (Cohen, 1978)

Cohen views that Marx practices functional thinking in the examples above and throughout his work because he seeks to explain an economic phenomenon in this manner (see Appendix B). With this, Cohen hoped to reintegrate Marx conflict theory into functionalism. Cohen took pains to explain that functional thinking which Marx work has exemplified is objectionable to structuralfunctionalism in view of its conservation posture. Cohen regard Marx not just a conflict but also a functionalist theorist (Cohen, 1978).

Also, Jon Elster, a major proponent along with John Roemer, of Analytical Marxism believes the neo-Marxian theory has been impeded by its adoption of the kind functional theorizing discussed by Cohen. He rather suggested that Marxian theory ought to be making greater use of Game theory, a variant of Rational Choice theory. In drawing upon this approach, Marxian theory would give up pretentions of being different by utilizing approaches widely used throughout social sciences (Elster, 1986). With this in mind, Elster consciously intended to integrate neo-classical economics into mainstream Neo-Marxian theory.

Also, Wright in his empirical study of class of class argued with the Neo-Marxist that a given position need not, as it is commonly assumed, be located within a given class; it may be in more than one class simultaneously. Thus, a position may be simultaneously proletarian and bourgeois. For example, managers are bourgeois. For example, managers are bourgeois in the sense that they supervise subordinates, but they are also proletarian in that they are supervise subordinates, but they are also proletarian in that they are supervised by others. With this, Wright employed scientific research and empiricism into Post-Marxism rather than depended on historicism of traditional Marxism.

\section{Neo-Marxism, Post-Marxism and Theoretical Modification}

Most of the ideas advanced by neo-Marxian and post- Marxian theorist aims at expanding Marxian ideas to meet modern situations. By so doing they seem to modify theoretically and synthesize those aspects of Marx's theory that are not tenable in contemporary social world by introducing elements of other theories that can pep it up as grand theory within the mainstream Sociology.

The view that economy is the primary sector of the social system and extend influence over other superstructure of the society has been seriously frowned at by neo-Marxists. All institutions of society are important and they are interdependent, interrelated and interconnected. Moreover, the idea that man is alienated from the product of his labour appears not objectively true and scientifically provable as Neo-Marxists discloses that product does not exist independent of the producers, they are interdependent and it is people that give them their values.

Moreover, domination and control have been regarded as a product of the differential ownership of economic resources. But emerging neo- Marxian ideas reveal technology, culture and knowledge industry as well as world system as potent sources of 
contemporary form of domination and control. Equally, Marx divided a given position into a single class but empirical study by neo-Marxists reveal that a given position need not be located in one class but simultaneously in different classes.

By isolating elements of functional theorizing in Marx work, the post- Marxists hoped to integrate Marxism into functionalism and functionalism into conflict theory (see Appendix B). More so, the advocacy of Marxism to employ rational choice orientation (Game Theory) into its work is an attempt by post- Marxist to incorporate neo-classical economic theory into Marxism. Due to their emphasis on class consciousness by neo- Marxists, some elements of Freudian theory were introduced into Marxism. It was Freud's believe that although people are controlled and imbued with false needs, they are also endowed with libido which provides energy for creative action especially towards the overthrow of major forms of domination.

Ultimately while neo-Marxian theorists were interested in enriching the contents and texture of Marxism, that is, modifying Marxism, post-Marxism thus aimed at making it a grand theory especially by synchronizing non-Marxists methods into Marxist theory. Mayer (1994) in Ritzer (1996: 169) regards these efforts as bringing the 'State-of-the-art methods of analytical philosophy and social science to bear on Marxian substantive issues'.

\section{Conclusion}

This paper examined a wide range of approaches that can be categorized into neo-Marxian and post-Marxian sociological theories. All of them take Marx's work as their point of departure, but went in very different directions with the hope of arriving at a theoretical synthesis. While neo-Marxian theories such as Hegelian Marxism, Critical Theories, and Historically Oriented Marxism vigorously integrated new ideas with the hope of modifying Marxism, Post- Marxian theories such as Analytical Marxism and Rational choice theory aims at incorporating aspects of other theories that could enhances Marxism as a general theory of social science. Hence, this paper has discussed exhaustively issues raised by neo-Marxists and Post-Marxism bordering Marxism with a view to modifying it to become a ground theory.

\section{References}

i. Andre, Georz (1975). Socialism and Revolution. London: Penguin Books.

ii. Aronson, R. (1995). After Marxism. New York: Guilford.

iii. Baran, P. and Sweezy, P. M. (1966). Monopoly capital: An Essay on the American Economic and Social Order. New York: Monthly Review Press.

iv. Braverman, H. (1994). Labour and Monopoly Capital: The Degradation of Work in the Twentieth Century. New York Monthly Review Press.

v. Charles, J. O. (2005). Sociological Theory: A Historic-Analytical Approach on Man and Society. Lagos: Serenity Printing and Publishing Co.

vi. Cohen G. (1996). Karl Marx's Theory of History: A Defence. Princeton, N.J.: Princeton University Press.

vii. Cook, D. (1996). The Culture Industry Revisited: Theodor N. Adorno on Mass Culture. Lanham, M D: Rowman and Little Field.

viii. Elster, J. (1986). Further Thoughts on Marxism, Functionalism, and Game Theory in J. (ed.), Analytical Marxism. Cambridge: Cambridge University Press.

ix. Friedman, G. (1981). The Political Philosophy of the Frankfurt School. Ithaca, N.Y.: Cornell University Press.

x. Gramsci, A. (1917/1977). The Revolution against Capital. In Hoare, Q. (ed)., Antonio Gramsci: Selections from political writings (1910-1920). New York: international Publishers. PP. 34-37.

xi. Habermas, J. (1994). The Past as Future. Interviewed by Michael Haller. Lincoln: University of. Nebraska Press.

xii. Harambos, M and Heald, R. M. (1980). Sociology: Themes and Perspectives. New York: Oxford University Press.

xiii. Kellner, D. (1990). Television and the Crises of Democracy. Boulder, Colo; Westview press.

xiv. Kolakowski, L. (978). Main Currents of Marxian. P.12

xv. Lukacs, G. (1922/1968). History and Class Consciousness. Cambridge, Mass: MIT PASS.

xvi. Marcuse, H. (1969). An Essay on Liberation. Boston Beacon. Press.

xvii. Marx, K. and Engels, F. (1848). The Communist Manifestos. Penguin Books

xviii. Ritzer, G. (1996). Modern Sociological Theory. New York: McGraw Hill.

xix. Schroyer, T. (1970). Towards a Critical Theory of Advanced Industrial society In H.P. Drieitzel (ed.). Recent Sociology: No. 2. New York: Macmillan.

xx. Tar, Z. (1997). The Frankfurt School: The Critical Theories of Max Herkimer and Theodor W. Adorno. London: Routledge and Kegan Paul.

xxi. Timasheff, N. S. (1957). Sociological Theory, its Nature and Growth. New York: Random House.

xxii. Wallerstein, I. (1994). The Modern World-System: Capitalist Agriculture and The Origins of the European World Economy in the 16th Century. New York: Academic Press.

xxiii. Welds, J. (1989). Marxism and Methodological Individualism: Theory and Society. 18:353-386

xxiv. Zipes, J. (1994). Adorno May Still be Right. Telos 101.157-167. 


\section{Appendix A}

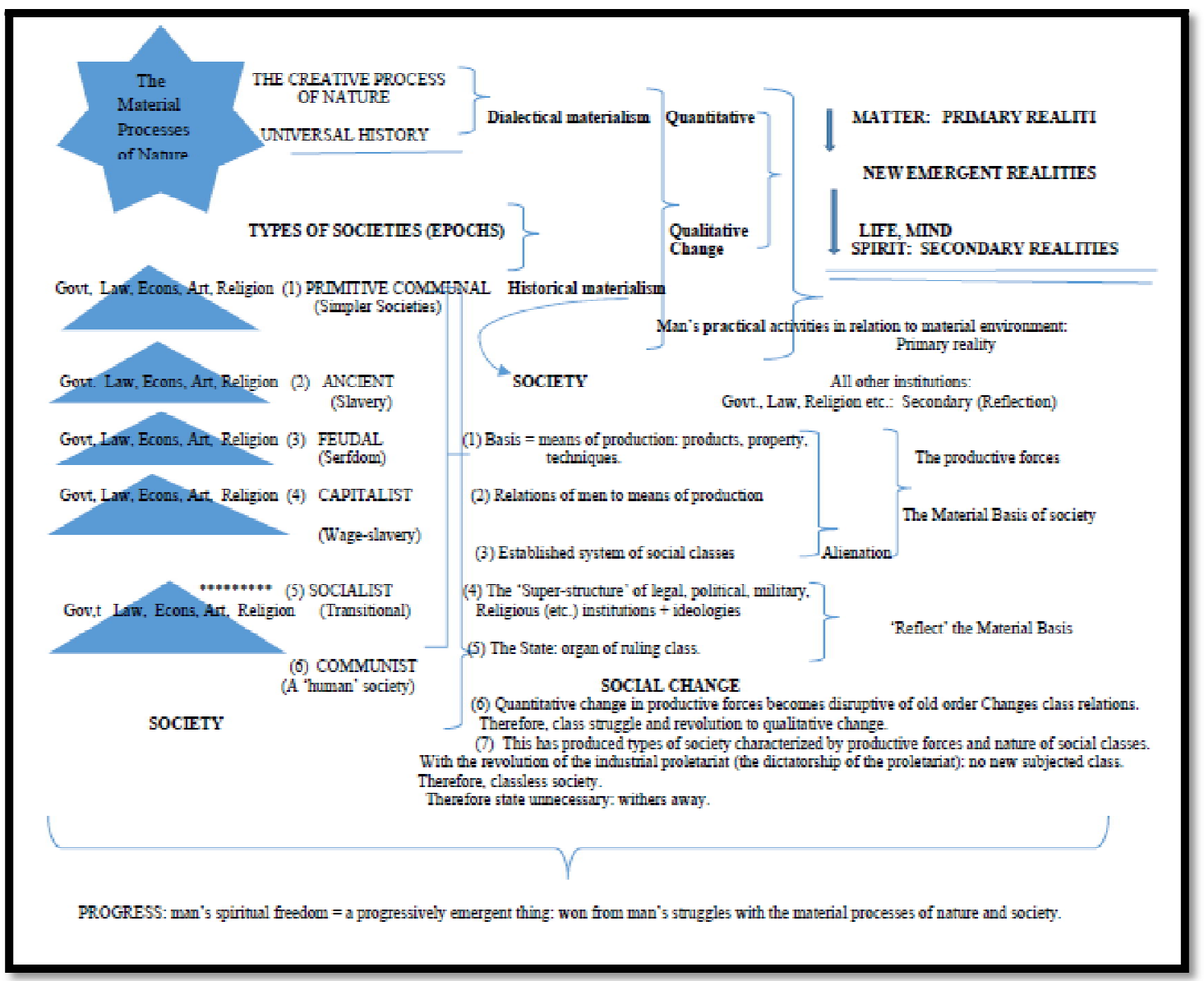

Marx: A Materialist Philosophy of History

Source: Adapted from Ronald Fletcher (1972). The Making of Sociology: Beginnings \& Foundations. Great Britain: Nelson's University Paperbacks. Pp.346

\section{Appendix B}

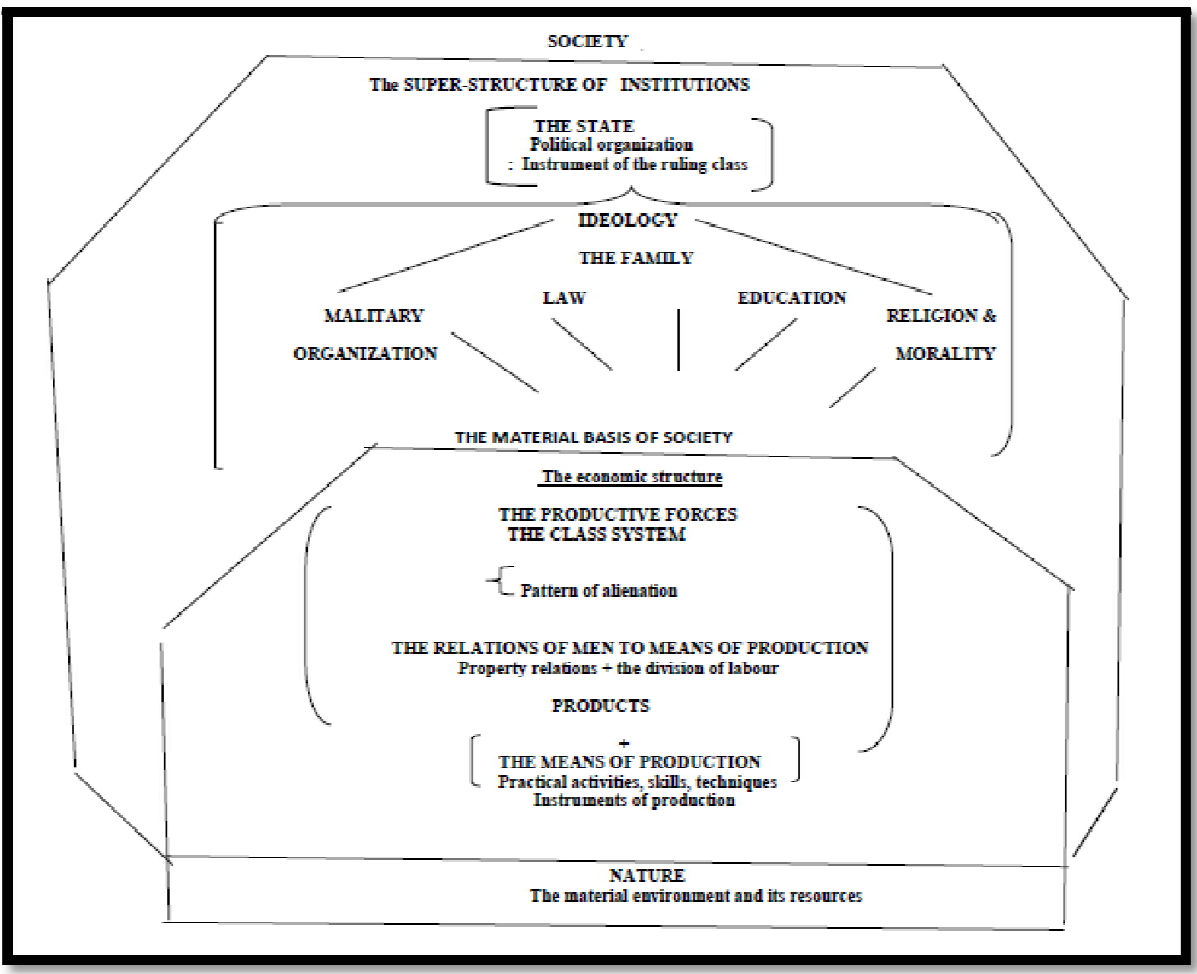

Marx: A Structural - Functional Model of Society

Source: Adapted From Ronald Fletcher (1972). The Making of Sociology: Beginnings \& Foundations, Great Britain: Nelson's University Paperbacks. Pp.391 